\title{
PSEUDOSCYMNUS, A NEW GENUS OF ASIATIC SCYMNINI (COLEOPTERA: COCCINELLIDAE)*
}

\author{
By Edward A. Chapin \\ Museum of Comparative Zoology
}

In the course of work on a report on the Coccinellidae of Micronesia, my attention was attracted by the figure of the antenna of Scymnus kurohime Miyatake and the figures of receptacula of unusual form of several species, mostly from Japan. Paratypes of $S$. kurohime were generously presented to me by Mr. M. Miyatake and a series of this species was found in a collection from Naha, Okinawa, made by Mr. N. L. H. Krauss. Mr. Miyatake also supplied, at my request, a series of $S$. hareja Ws. An analysis of the characters of these species shows that they form a group which is intermediate between Scymnus proper and Cryptogonus. It should be noted here that the eyes of Cryptogonus and its close relatives are sparsely set with fine erect setae, a character which has long been recognized as definitive of the Scymnini.

When compared with Scymnus nigrinus Kugel. and Cryptogonus orbiculus (Gyll.), the respective type-species, one finds the characters of $S$. hareja and $S$. kurohime to be closer to Cryptogonus than to Scymnus. In Scymnus the antenna is of the usual coccinelline form and consists of eleven segments. The tarsus is also similar to the large majority of coccinellids in being composed of four segments. In Cryptogonus and Pseudoscymnus the antenna is very short and consists of nine segments and is of an unusual form for the family. The tarsus is truly three segmented, differing from those of most coccinellids.

\section{Genus Pseudoscymnus new genus}

Body form and size of Scymnus Kugelann, upper surface set with fine, short pubescence. Antenna nine-segmented; basal segment stout, almost as wide at its widest part as long; second segment stout barrelshaped, nearly equilateral, clearly separated from the basal; third through ninth segments forming a fusiform club, the third longer than wide, fourth through seventh wider than long, each wider than the preceding, eighth segment usually shorter than wide and slightly narrower than seventh, ninth segment a little more than half as

*Manuscript reccived by the editor March 30, 1962. 
wide as eighth, subconical. The ninth segment bears at its apex several long setae. Maxillary palp with the three segments nearly equal in width, the terminal segment parallel-sided with apex sharply oblique. Terminal segment of labial palp stout barrel-shaped with truncate apex. Mandible with subapical tooth. Prosternum not produced anteriorly to cover mouthparts, prosternal lobe rather narrow, carinate. Abdomen with six visible sternites. Coxal arc incomplete, much as in Nephus Mulsant. Tibiae simple, rather slender. Tibial spurs absent. Tarsus three segmented. Claw with subquadrate basal tooth. Elytral epipleura nearly flat and horizontal, not distinctly foveolate.

Male - aedeagus symmetrical.

Female - receptaculum seminis with ramus short and stout, nodulus long, drawn out in a slender, curved tube, or short and stout, cornu curved, sausage-shaped. Sperm duct very short if nodulus is elongate tubular, otherwise moderately long. Infundibulum absent. Hemisternites intermediate between the "blade and handle" type of the majority of the Coccinellidae and the "ovipositor" type of most of the Scymnini.

Type-species - Scymnus hareja Weise.

I am including the following species in Pseudoscymnus -

Pseudoscymnus hareja (Ws.) I 879, Deutsch. ent. Zeit., 23: I50; Miyatake, 1958, Japanese Journ. Appl. Ent. Zool., 2:25 I256. figs. I A-D, 3 A-B, 4 E-H, 5 A-C.

Pseudoscymnus kurohime (Miyatake) I959, Mem. Ehime Univ., (6) $4: \mathrm{I} 36-\mathrm{I} 38$, figs. 50-6r.

It is probable that the following four species also should be referred to Pseudoscymnus -

Scymnus seboshii Ohta I929, Ins. Matsumurana, 4: II; Miyatake, I958, Japanese Journ. Appl. Ent. Zool., 2: 25 I256, figs. 2 A-C, 3 C-D, 4 A-D, 5 D-F.

Scymnus sylvaticus Lewis I896, Ann. Mag. Nat. Hist., (6) I7:36; Bielawski I957, Trans. Shikoku Ent. Soc., 5:7I, figs. 5-I I.

Scymnus pilicrepus Lewis I 896, op. cit., p. 36; Bielawski, I957, op. cit., p. 72-73, figs. I 2-I 5 .

Scymnus quinquepunctatus Weise, 1923, Arch. Naturg., 89. A. 2: 188; Miyatake 1959, Mem. Ehime Univ., (6) 4: 138, figs. $62-64$. 

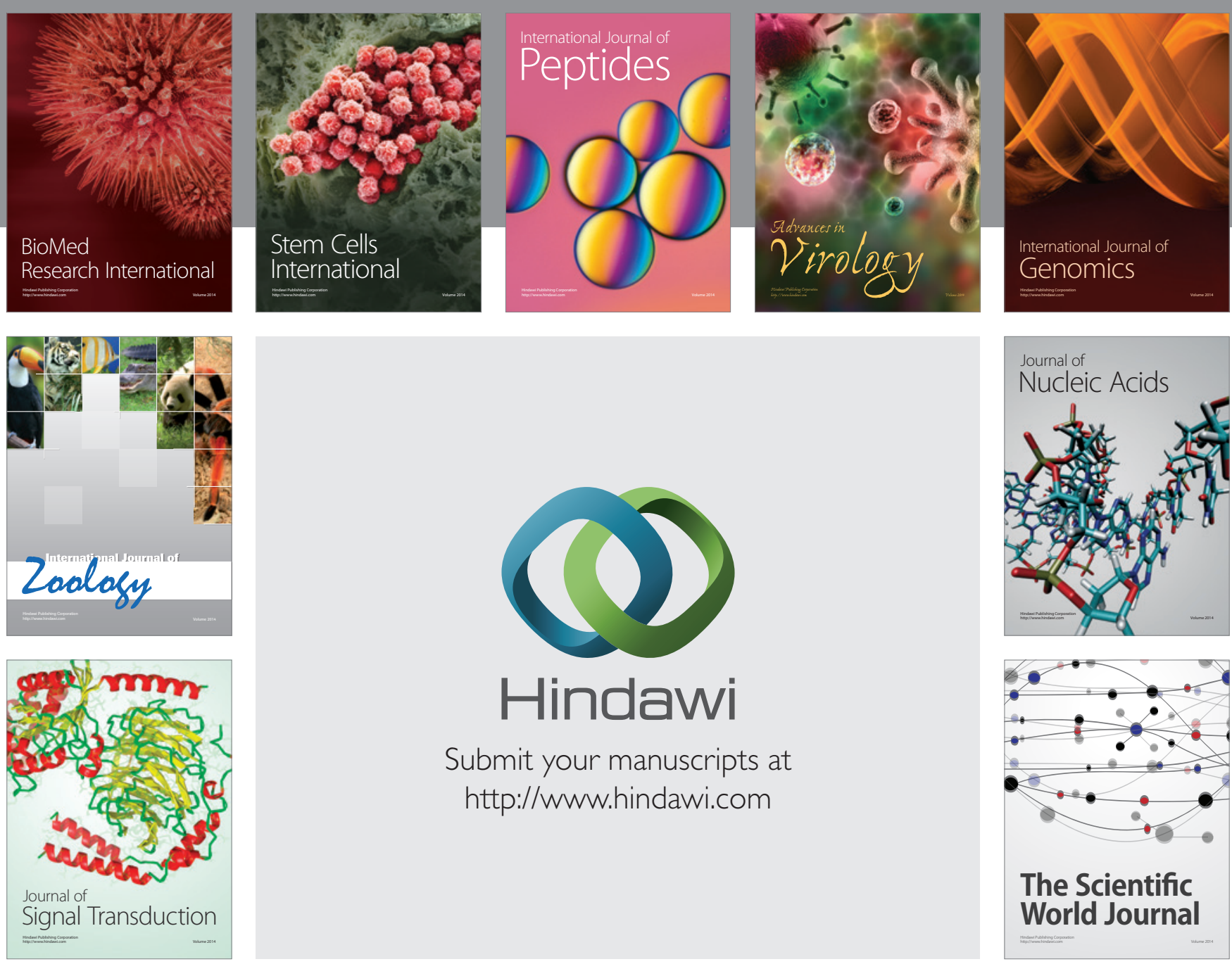

Submit your manuscripts at

http://www.hindawi.com
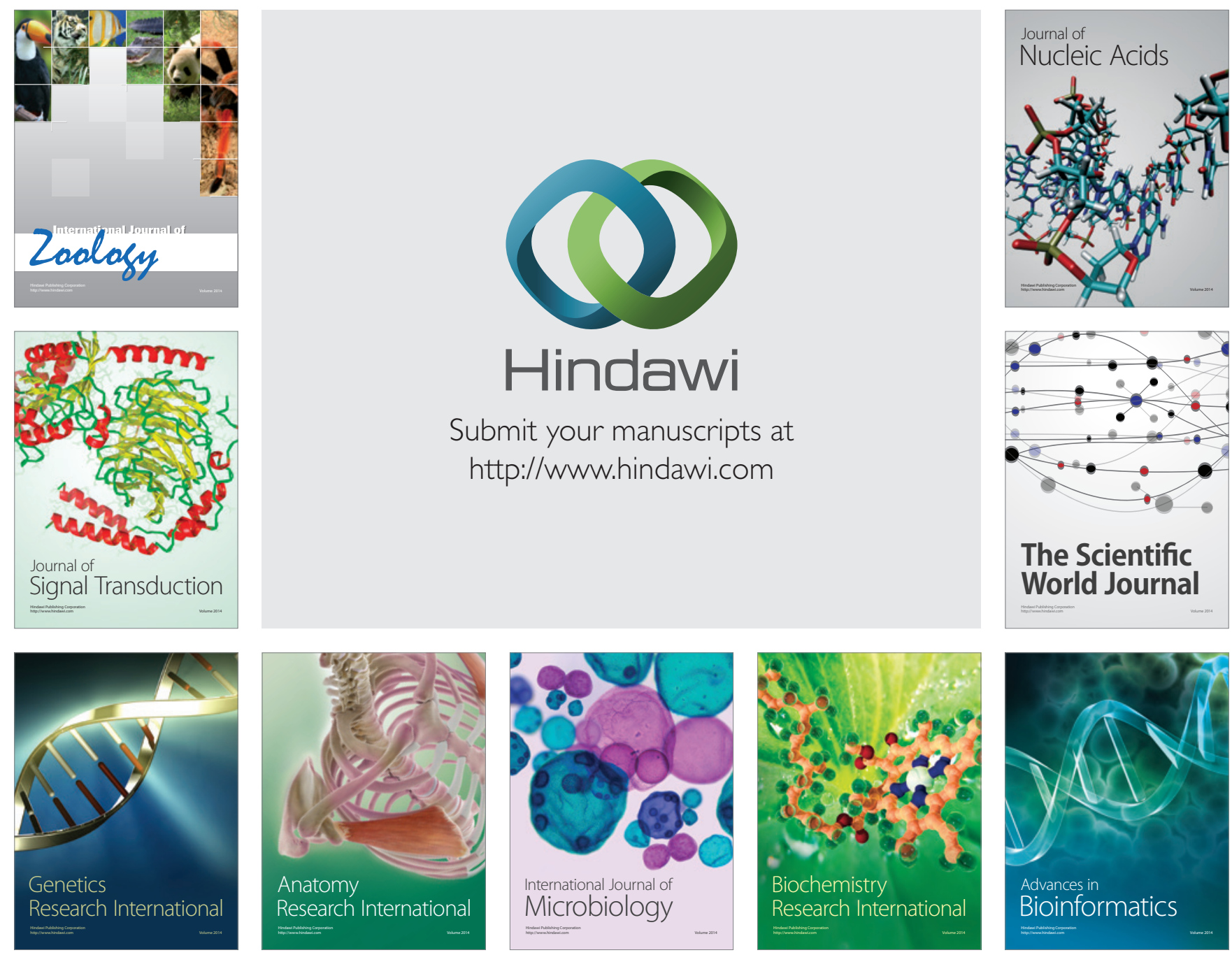

The Scientific World Journal
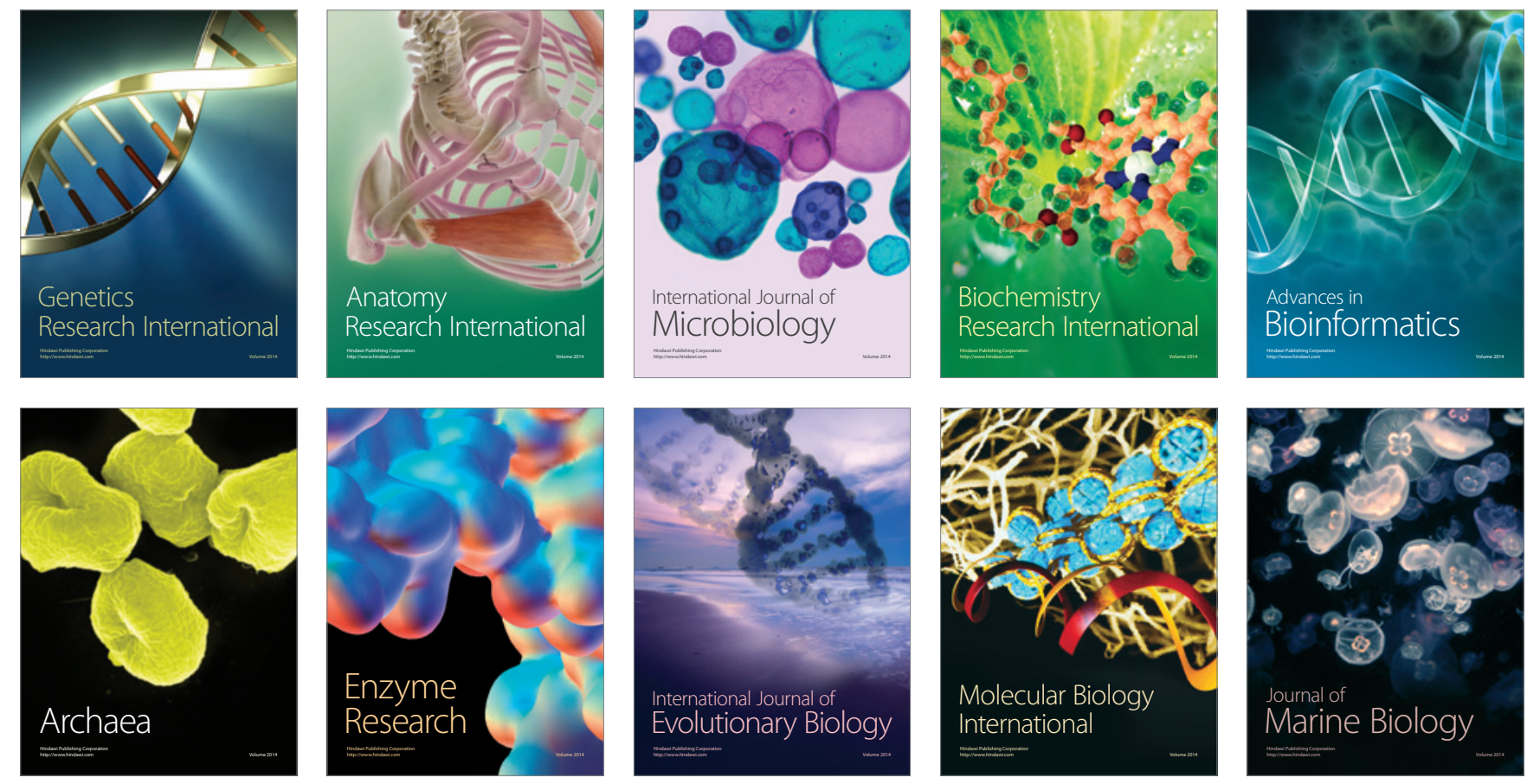